\title{
Aplikasi Sistem Absensi Karyawan Dengan Menggunakan Metode Barcode Pada PT. XYZ
}

\author{
Hari Purwanto \\ hari_1271@yahoo.co.id
}

\begin{abstract}
ABSTRAK
PT. XYZ merupakan sebuah perusahaan berskala menengah yang bergerak di bidang penyediaan berbagai macam bahan eksterior dan interior bangunan. Pada perusahaan ini terdapat suatu sistem absensi karyawan yang masih berjalan secara manual, dimana dalam penerapan sistem absensi ini terdapat beberapa hal yang menjadi kendala, yaitu diantaranya adalah keefektifan dan efisiensi waktu dan proses pengabsenan, bentuk laporan absensi yang masih berupa hardcopy yang dapat menyulitkan dalam proses pencarian data, dan kemungkinan terjadinya data absensi yang hilang.

Dengan alasan di atas maka penulis mencoba untuk memberikan alternatif pemecahan masalah dengan membuat suatu aplikasi sistem sbsensi yang akan mencatat data dan daftar kehadiran karyawan, waktu kedatangan, waktu pulang, yang akan dibuat secara sistematis dan terkomputerisasi dengan metode barcode, sehingga akan menghilangkan proses pencatatan kehadiran karyawan yang selama ini telah berjalan secara manual pada PT. XYZ dan juga dengan penggunaan metode barcode akan mengurangi tingkat kesalahan penginputan ID Pegawai dalam proses absensi tersebut.

Pada penulisan ini juga akan diterangkan tahapan pengerjaan, mulai dari proses analisa, perencanaan, konstruksi yang menggunakan aplikasi berbasis web, hingga tahapan pengimplementasian dengan menggunakan metode spiral dengan notasi perekayasaan dan pendekatan berorientasi objek, UML (Unified Modelling Languange), dengan membuat use case diagram, sequence diagram, class diagram, flow map (sebagai indikasi prosedur arus data pada sistem yang akan diterapkan dan analisa masukan), dan analisa masukan dan keluaran, untuk mengetahui data apa saja yang menjadi masukan dan keluaran.
\end{abstract}

Kata Kunci : Barcode, Aplikasi Sistem Absensi, ID Pegawai, UML, Use Case Diagram, Sequence Diagram, Class Diagram, Flow Map.

\section{PENDAHULUAN}

Perkembangan dunia teknologi informasi saat ini semakin cepat memasuki berbagai bidang, sehingga kini semakin banyak perusahaan yang berusaha meningkatkan usahanya terutama dalam bidang bisnis yang sangat berkaitan erat dengan teknologi informasi itu sendiri. Hal ini didukung oleh pernyataan bahwa Kegunaan komputer pada aplikasi bisnis adalah untuk menyediakan informasi dengan cepat dan tepat. Informasi ini ibarat darah yang mengalir di dalam tubuh suatu perusahaan. Jika di dalam suatu perusahaan, informasi tersebut terhenti atau terhambat, maka sistem perusahaan akan menjadi lusuh (Jogiyanto, 1999:96).

Salah satu perkembangan teknologi informasi yang penting adalah 
semakin dibutuhkannya penggunaan alat pengolah data yang berfungsi untuk menghasilkan informasi yang dibutuhkan. Perusahaan-perusahaan yang ingin mengembangkan usaha dan mencapai sukses harus mengikuti era informasi dengan menggunakan alat pendukung pengolah data yaitu komputer. Hal ini didukung oleh pernyataan yang diutarakan bahwa komputer digunakan untuk mengelola sumber daya yang luas dari perusahaan-perusahaan yang memandang seluruh dunia sebagai pasar mereka dimana pada eksekutif perusahaan melakukan investasi pada teknologi informasi dengan tujuan mencapai skala ekonimis dan dapat mengembangkan produk yang dapat dijual di seluruh dunia (Mcleod,1998:9).

Dalam kajian ini penulis ingin memberikan suatu solusi dengan merancang dan mengaplikasikan suatu alur kerja sistem absensi berdasarkan sistem absensi manual yang sudah ada pada PT. XYZ yang masih kurang efektif dan efisien, dan membuat sistem basis data yang akan digunakan dalam aplikasi absensi yang terkomputerisasi, user Interface untuk mengelola basis data tersebut dan aplikasi absensi yang terkomputerisasi dengan baik antara sistem basis data, user interface, dan user itu sendiri dengan penambahan metode barcode untuk memberikan solusi optimal yang telah terkomputerisasi, kecepatan dan ketepatan pengolahan data, dan mengurangi tingkat kesalahan pada waktu proses pengabsenan berlangsung (http://www.wikipedia.com/barcode).

Proses pengabsensian yang telah ada di PT. XYZ dapat dikatakan masih kurang efisien dan efektif karena semua masih dilakukan secara manual, mulai dari pendataan dan penghitungan jam hadir, jam keluar, lama waktu kerja, sampai dengan keterangan tidak masuk karyawan. Sedangkan di departemen personalia, pengaksesan ini belum memiliki sesuatu sistem informasi pegawai yang baik. Semua hal tersebut sering mengakibatkan hasil yang kurang teliti dan memakan waktu yang lama. Masalah yang utama yang timbul dikarenakan adanya faktor kelelahan mental akibat hanya ada seorang staff yang bertanggung jawab dalam perhitungan jam kerja.

Penggunaan metode barcode pada aplikasi sistem absensi karyawan ini juga akan membuat sistem absensi ini menjadi lebih efektif dan efisien karena setiap pegawai hanya akan menempelkan kartu ID karyawan pada perangkat barcode scanner yang telah tersedia dimana penghitungan jam hadir dan jam keluar karyawan akan masuk pada database, kemudian hasil inputan nomor induk karyawan atau barcode akan menjadi acuan jam kedatangan karyawan tersebut.

Dalam penulisan ilmiah ini, penulis akan memberikan suatu solusi tentang:

1. Bagaimana sistem absensi ini dapat membantu proses pencatatan data dan daftar hadir karyawan.

2. Bagaimana memberikan report harian, bulanan, dan tahunan data dan daftar hadir karyawan.

Metode yang digunakan dalam perancangan dan pengembangan sistem 
aplikasi absensi karyawan ini adalah dengan menggunakan beberapa metode, antara lain :

1. Metode Interview

2. Metode Pengembangan Sistem : Model Spiral \& UML

\section{LANDASAN TEORI}

Metode pengembangan sistem yang digunakan dalam pembahasan ini adalah dengan menggunakan Model Spiral. Model spiral yang pada awalnya diusulkan oleh Boehm (1988), merupakan suatu model proses perangkat lunak yang evolusioner yang merangkai sifat iteratif dari prototipe dengan cara kontrol dan aspek sistematis dari model sekuensial linear. Model ini berpotensi untuk pengembangan versi pertambahan perangkat lunak secara cepat.

Setiap untai pada spiral merepresentasikan proses perangkat lunak, dengan demikian untai yang paling dalam mungkin berkenaan dengan kelayakan sistem, untai berikutnya dengan definisi peersyaratan sistem dan untai berikutnya lagi dengan perancangan sistem, demikian seterusnya.

Metode pengembangan sistem yang digunakan dalam penulisan skripsi ini adalah dengan menggunakan model pengembangan sistem spiral. Model Spiral yang diusulkan oleh Boehm, menggambarkan sebuah tahapan proses pengembangan perangkat lunak, yang terdiri dari Tujuh wilayah tugas sebagai berikut:

1. Komunikasi Pelanggan

Tugas-tugas yang dibutuhkan untuk membangun komunikasi yang efektif di antara pengembang dan pelanggan. Komunikasi pelanggan ini dilakukan dengan cara mewawancarai pihak yang terkait mengenai sistem yang akan dijalankan nantinya, sehingga didapatkan gambaran awal sistem yang akan dikerjakan.

Beberapa pertanyaan yang diharapkan mampu untuk menjawab kebutuhan awal dari sistem absensi yang akan dijalankan pada PT. XYZ antara lain yaitu :

A. Siapa saja orang yang akan mempergunakan aplikasi absensi ini?

B. Siapa yang akan menjadi operator dan administrator yang akan mengelola dan memelihara sistem absensi ini?

C. Input dan output yang diharapkan dari aplikasi absensi ini?

D. Seberapa efektif aplikasi absensi ini dapat membantu kinerja pegawai dalam perusahaan?

E. Berapa lama aplikasi ini akan dibuat?

F. Berapa estimasi biaya yang dibutuhkan dalam pembuatan aplikasi absensi ini?

G. Objek-objek apa saja yang ada dan akan ditambahkan dalam aplikasi absensi ini?

H. Spesifikasi perangkat dan alat apa saja yang dibutuhkan dalam mendukung pembuatan aplikasi absensi ini?

2. Perencanaan

Pada tahap perencanaan ini dilakukan suatu pendefinisian tentang sumber daya yang akan menunjang 
dan mandukung pengelolaan dan pemeliharaan aplikasi absensi ini, ketepatan waktu dalam penyelesaian pembuatan aplikasi absensi, dan informasi lain yang berhubungan dengan pembaharuan atau pengembangan sistem secara menyeluruh yang akan berjalan pada perusahaan XYZ.

\section{Analisa Resiko}

Tugas-tugas yang dibutuhkan untuk menaksir resiko-resiko, baik manajemen maupun teknis. Tahap ini merupakan tahap penelitian untuk merancang atau memperbaiki suatu sistem dan akan dimplementasikan dalam hal ini pada PT. XYZ, dengan cara penguraian masalah dari suatu sistem informasi secara utuh ke dalam bagian-bagian komponennya dengan maksud un- tuk mengidentifikasi dan mengevaluasi permasalahan yang ada, kesempatan, peluang, keuntungan, hambatan dan identifikasi segala kebutuhan untuk system yang sedang dianalisa.

Selama proses analisis resiko, setiap resiko yang teridentifikasi diperhitungkan secara bergantian dan penilaian mengenai besarnya probabilitas dan keseriusan probabilitas tersebut pun dibuat (Sommerville, 2000:82).

Pada tabel di bawah ini akan dituliskan beberapa resiko yang mungkin akan dihadapi pada tahap pembuatan dan pengimplementasian aplikasi absensi karyawan ini:

Tabel 2.1 Analisis Resiko Aplikasi Sistem Absensi

\begin{tabular}{|c|l|c|c|}
\hline No & \multicolumn{1}{|c|}{ Resiko } & Probabilitas & Efek \\
\hline 1 & Waktu pengerjaan yang relatif singkat & Sedang & Dapat \\
\hline 2 & $\begin{array}{l}\text { Diusulkan perubahan teradap persyaratan yang } \\
\text { menuntut dilakukannya perancangan ulang }\end{array}$ & Sedang & Serius \\
\hline 3 & Case tool tidak dapat diintegrasikan & Tinggi & Dapat \\
\hline 4 & $\begin{array}{l}\text { Perancangan database, tampilan, input dan } \\
\text { output, }\end{array}$ & Tinggi & Serius \\
\hline 5 & $\begin{array}{l}\text { Database yang digunakan pada sistem tidak } \\
\text { dapat memproses transaksi per detik sebanyak } \\
\text { yang diharapkan }\end{array}$ & Sedang & Serius \\
\hline 6 & $\begin{array}{l}\text { Komponen perangkat lunak yang harus dipakai } \\
\text { ulang mengandung kelemahan yang membatasi } \\
\text { fungsionalitasnya }\end{array}$ & Sedang & Serius \\
\hline 7 & $\begin{array}{l}\text { Pelanggan tidak memahami dampak perubahan } \\
\text { sistem }\end{array}$ & Sedang & $\begin{array}{c}\text { Dapat } \\
\text { ditolerir }\end{array}$ \\
\hline
\end{tabular}


Analisa resiko yang coba penulis perkirakan dalam pembuatan aplikasi absensi ini yaitu analisa dalam resiko teknis yang mengidentifikasikan berbagai hal yang berkaitan dengan resiko yang ada pada tahap perancangan aplikasi seperti spesifikasi perangkat yang digunakan, desain interface aplikasi, verifikasi, implementasi, dan pemeliharaan.

Dalam kegiatan analisa ini penulis mengumpulkan data serta tujuan yang akan dicapai berkaitan dengan kegiatan analisa. diantaranya, yaitu:

A. Analisa dan Deskripsi Sistem Lama

Tujuannya yaitu untuk menganalisa dan mengetahui sistem lama yang telah berjalan pada PT. XYZ sebelumnya dan mendeskripsikan sistem lama tersebut sehingga dapat diketahui kekurangan dan kelebihan dari sistem yang ada termasuk didalamnya profil dari perusahaan PT. XYZ.

B. Identifikasi Permasalahan Yang Dihadapi

Tujuannya yaitu untuk mengidentifikasi jenis permasalahan yang dihadapi, mengetahui penyebab timbulnya masalah dalam sistem yang sedang berjalan dan menciptakan suatu solusi untuk memperbaiki sistem yang ada.

C. Alternatif Penyelesaian Masalah

Tujuannya yaitu untuk memberikan usulan penyelesaian masalah yang ada pada PT.
XYZ dengan membuat usulan sistem yang baru dengan metode pendekatan sistem berorientasi objek, yakni dengan membuat :

1) Use case Diagram

2) Sequence Diagram

3) Class Diagram

4) Flow Map, sebagai indikasi prosedur arus data pada sistem yang akan diterapkan dan analisa masukan

5) Analisa Masukan dan Keluaran, untuk mengetahui data apa saja yang menjadi masukan dan keluaran data yang berjalan.

\section{Perekayasaan}

Tugas-tugas yang dibutuhkan untuk membangun satu atau lebih representasi dari aplikasi tersebut.. Dalam tahap perekayasaan ini Penulis menggunakan beberapa tools (alat) dalam membuat rancangan sistem, yaitu antara lain:

A. Kebutuhan Umum Sistem

Tahapan ini bertujuan untuk merancang suatu kebutuhan/ requirement dari sistem yang diharapkan mampu untuk menghasilkan keluaran sesuai dengan yang diharapkan pelanggan dalam hal ini PT. XYZ termasuk didalamnya fungsionalitas dan pengguna dari sistem aplikasi absensi ini.

B. Pengembangan Sistem

Tahapan ini bertujuan untuk merancang lingkungan yang akan digunakan dalam pe- 
ngembangan program, yang meliputi jenis perangkat lunak (software) yang digunakan, sistem operasi yang digunakan, dan spesifikasi perangkat keras (hardware) yang digunakan.

C. Perancangan Sistem Baru

Dalam melakukan perancangan sistem, penulis menggunakan notasi UML sebagai case tool dalam perekayasaan sistem yang didalamnya terdapat identifikasi objek yang terkait dalam perancangan aplikasi absensi ini.

D. Perancangan Database

Setelah perancangan sistem dilakukan kemudian penulis merancang databasenya dengan menggunakan alat bantu Entity Relationship Diagram (ERD) yang menggambarkan hubungan antar entitas yang ada. Untuk mengefisiensikan dan mengefektifkan serta menghindari data yang sama, dalam basis data penulis juga melakukan normalisasi.

E. Perancangan Antarmuka

Setelah tabel dalam bentuk normal selesai dirancang barulah penulis melakukan rancangan antarmuka program baik untuk input dan output.

\section{Konstruksi dan Peluncuran}

Tugas-tugas yang dibutuhkan untuk mengkonstruksi, menguji, memasang dan memberikan pelayanan kepada pemakai. Jika seluruh obyek yang dibutuhkan telah selesai didesain maka tahap selanjutnya adalah mengkonstruksikan obyek- obyek yang telah selesai didesain ke dalam kode bahasa pemrograman. Bahasa pemrograman yang di gunakan ialah PHP sebagai pembuatan aplikasi sistemnya dan menggunakan aplikasi perancangan database MySQL. Standarisasi barcode yang digunakan adalah barcode tipe code-39 dengan standar verifikasi barcode reader ANSI X3.182 yang merupakan UPC Code yang digunakan di US ANSI/UCC5 dan merupakan standar Amerika yang banyak digunakan pada beberapa sistem pembacaan barcode.

6. Evaluasi Pelanggan

Langkah ini melakukan pengujian fungsionalitas dan efisiensi sistem pada saat sistem tersebut telah selesai dibuat dan diimplementasikan.

7. Menarik Kesimpulan

Tugas-tugas yang dibutuhkan untuk memperoleh umpan balik dari pelanggan dengan didasarkan pada evaluasi representasi perangkat lunak, yang dibuat selama masa perekayasaan dan diimplementasikan selama masa pemasangan.

\section{PEMBAHASAN}

3.1 Analisa dan Deskripsi Sistem Lama

Berdasarkan hasil survei dan interview yang dilakukan mengenai prosedur pengabsenan pegawai, tahapan yang dilakukan PT. XYZ dalam tahap presensi ini adalah sebagai berikut:

1. Admin mencetak lembar kartu absensi pegawai 
2. Lembar kartu absensi diserahkan pada pihak manajemen personalia untuk divalidasi

3. Lembar kartu absensi tersebut diserahkan pada masing-masing pegawai untuk melakukan absensi

4. Admin/staff personalia merekap dan mendata semua lembar kartu absensi pegawai.

5. Admin/staff personalia melakukan penginputan secara manual pegawai yang telah melakukan proses presensi berdasarkan data pada lembar kartu absensi.

6. Data absensi pegawai ter-update.

7. Admin/staff personalia menyerahkan laporan data hadir pegawai ke bagian manajemen personalia untuk divalidasi.

\subsection{Identifikasi Permasalahan Yang Dihadapi}

Permasalahan yang dihadapi pada sistem manual seperti ini adalah:

1. Belum adanya sistem yang dapat mencegah pegawai untuk melakukan penitipan absen

2. Ketidakefisienan waktu yang digunakan untuk presensi
3. Belum adanya pengoptimalan penggunaan barcode pada kartu tanda pengenal/ID pegawai.

4. Input data presensi yang dilakukan satu-persatu secara manual oleh admin/staff personalia memungkinkan terjadinya kesalahan entry/penginputan data.

5. Sulit untuk mencari arsip laporan data presensi pegawai untuk pendataan ulang jika proses manual absensi telah berjalan lama (> 1Tahun).

\subsection{Flow Map}

FM (Flow Map) merupakan bagan alir yang menunjukkan arus data dari laporan dan form termasuk tembusantembusannya pada sistem. Flow map ini menggunakan simbol-simbol yang sama dengan yang digunakan di dalam bagan alir sistem. Jogiyanto H.M (2001:800).

Perancangan flow map yang berjalan pada PT. XYZ dapat dilihat pada gambar 4.2 di bawah ini : 


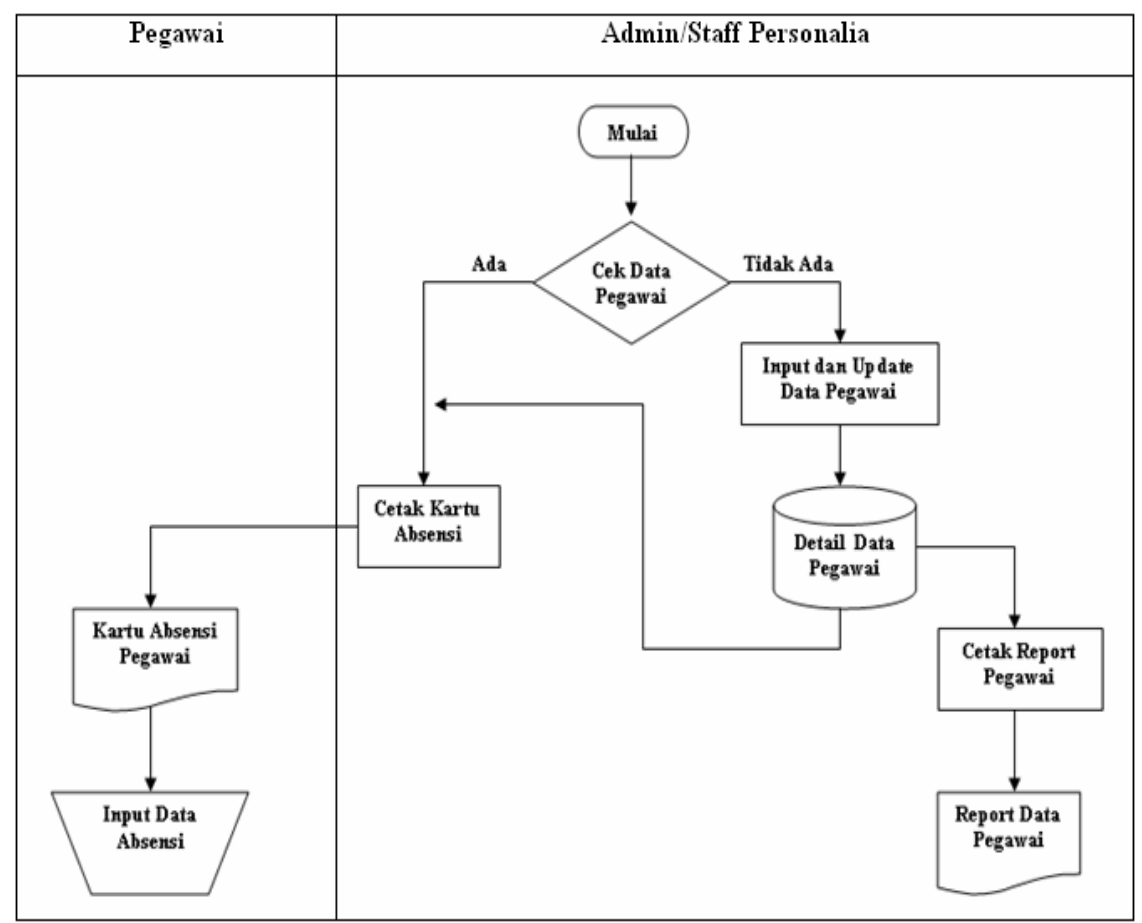

Gambar 3.1 Flow Map Yang Berjalan Pada PT. XYZ

\subsection{Alternatif Pemecahan Masalah}

Pemecahan masalah yang penulis gunakan dalam menyelesaikan masalah presensi pegawai di sini adalah dengan melakukan pergoptimalan penggunaan barcode. Data barcode akan dibentuk berdasarkan nomor induk pegawai yang akan tercantum dalam kartu pengenal/ ID Pegawai yang merupakan metode dari segi kepraktisan dan efisiensi waktu dalam melakukan proses pencatatan daftar kehadiran dan kepulangan pegawai.

\subsection{Kebutuhan Umum Sistem}

Kebutuhan umum sistem adalah sebagai berikut :

1. Mampu mengidentifikasi ID pegawai yang di-scan, apakah data pegawai tersebut ada dalam database pegawai dan ada dalam data daftar absensi pegawai.

2. Mampu menampilkan data dan daftar pegawai yang telah berhasil melakukan scan barcode pada saat proses absensi dilakukan.

3. Mampu melakukan rekapitulasi kehadiran pegawai

4. Mampu untuk memberikan laporan akhir data pegawai beserta data kehadiran pegawai berdasarkan waktu tertentu.

\subsection{Perancangan Flow Map \\ Perancangan flow map dari} aplikasi absensi pegawai ini dapat dilihat pada gambar 4.3 di bawah ini : 


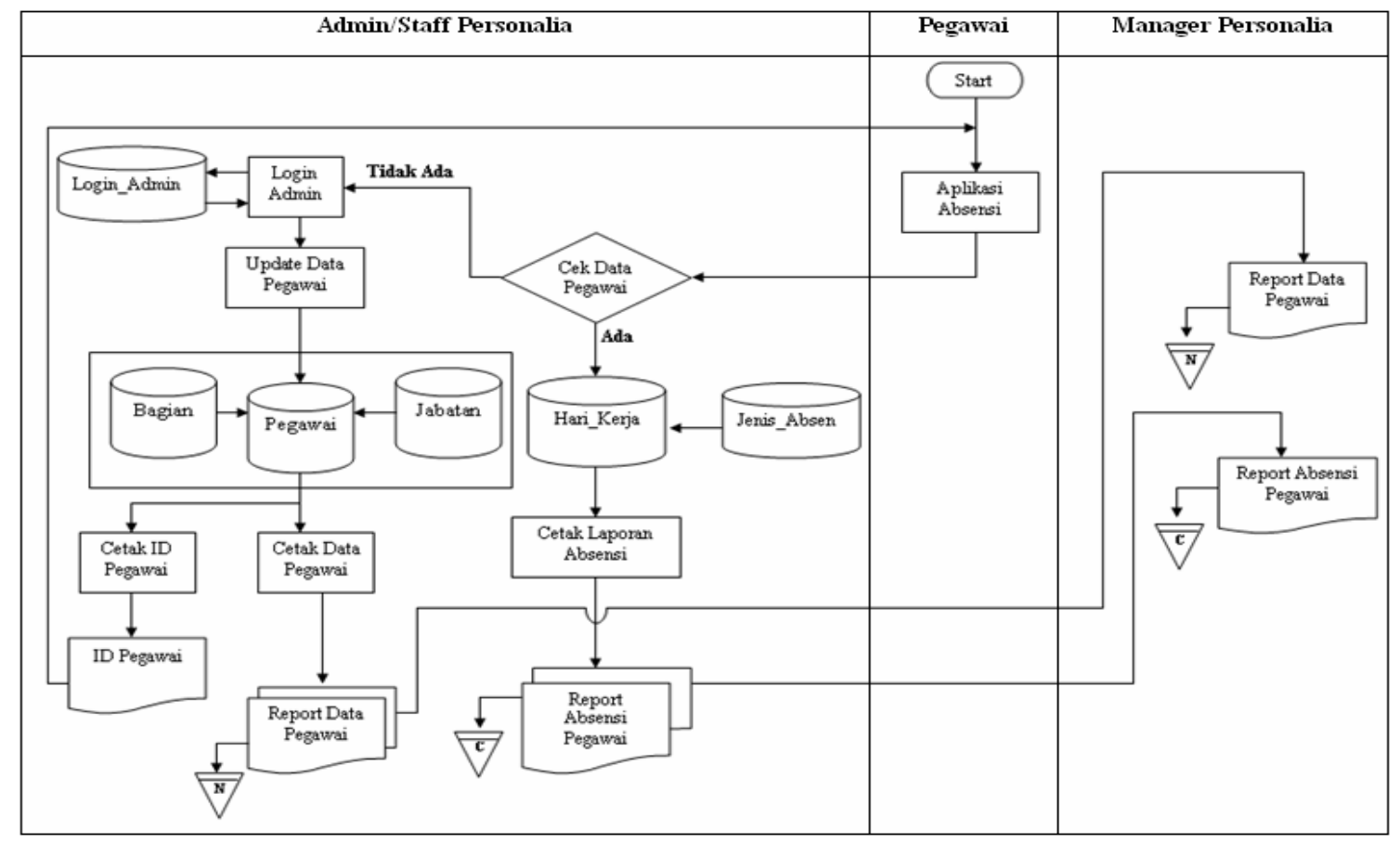

Gambar 3.3. Prosedur Perancangan Sistem Yang Diusulkan

Adapun prosedur dari perancangan sistem yang diusulkan adalah sebagai berikut:

1. Pegawai akan melakukan proses pengabsenan sebanyak dua kali. Pada proses yang pertama, aplikasi akan mencatat jam kedatangan karyawan, sedangkan pada proses yang kedua aplikasi akan mencatat jam kepulangan karyawan. Pencatatan absen jam masuk dan jam keluar dilakukan oleh karyawan dengan menggunakan kartu tanda pengenal (ID Card), yang didalamnya tercantum Nama Karyawan, Bagian dan Jabatan Karyawan, serta nomor ID Pegawai beserta kode barcodenya.
2. Pada saat karyawan melakukan proses pengabsenan yang pertama, aplikasi absensi ini akan memeriksa apakah data pegawai tersebut sudah terdaftar dalam aplikasi ini. Jika data pegawai tersebut telah ada, maka proses pengabsenan dapat dilakukan. Sebaliknya, jika data karyawan tersebut belum terdaftar, maka proses pengabasenan tidak dapat dilakukan.

3. Untuk data karyawan yang belum terdaftar, maka admin pengelola aplikasi absensi, dalam hal ini admin/ staff personalia harus mendaftarkan data karyawan yang dimaksud, termasuk didalamnya data pribadi karyawan, jabatan dan bagian karyawan, dan admin/staff personalia juga akan 
melakukan proses pencetakan kartu ID karyawan yang nantinya akan digunakan dalam melakukan proses absensi.

4. Pada proses pengabsenan, akan dibagi menjadi 3 kategori keterangan absen, yaitu: Masuk, Telat, dan Tanpa Keterangan yang nantinya akan tertulis pada data absensi karyawan dengan penentuan beberapa kondisi absensi.

5. Sistem akan mencetak alaporan data karyawan dan data absensi, yang nantinya akan dilaporkan pada manager personalia untuk divalidasi.

\subsection{Model UML}

3.8.1 Use Case Diagram

Pada Use case diagram ini menjelaskan apa yang akan dilakukan oleh sistem yang akan dibangun dan siapa yang akan berinteraksi dengan sistem. Use case diagram menjadi dokumen kesepakatan antara customer, User, dan Developer.

Berikut pada gambar 4.4 dan 4.5 adalah use case diagram dari aplikasi absensi ini, yaitu antara lain:

\section{Use Case Diagram Administrasi Pegawai}

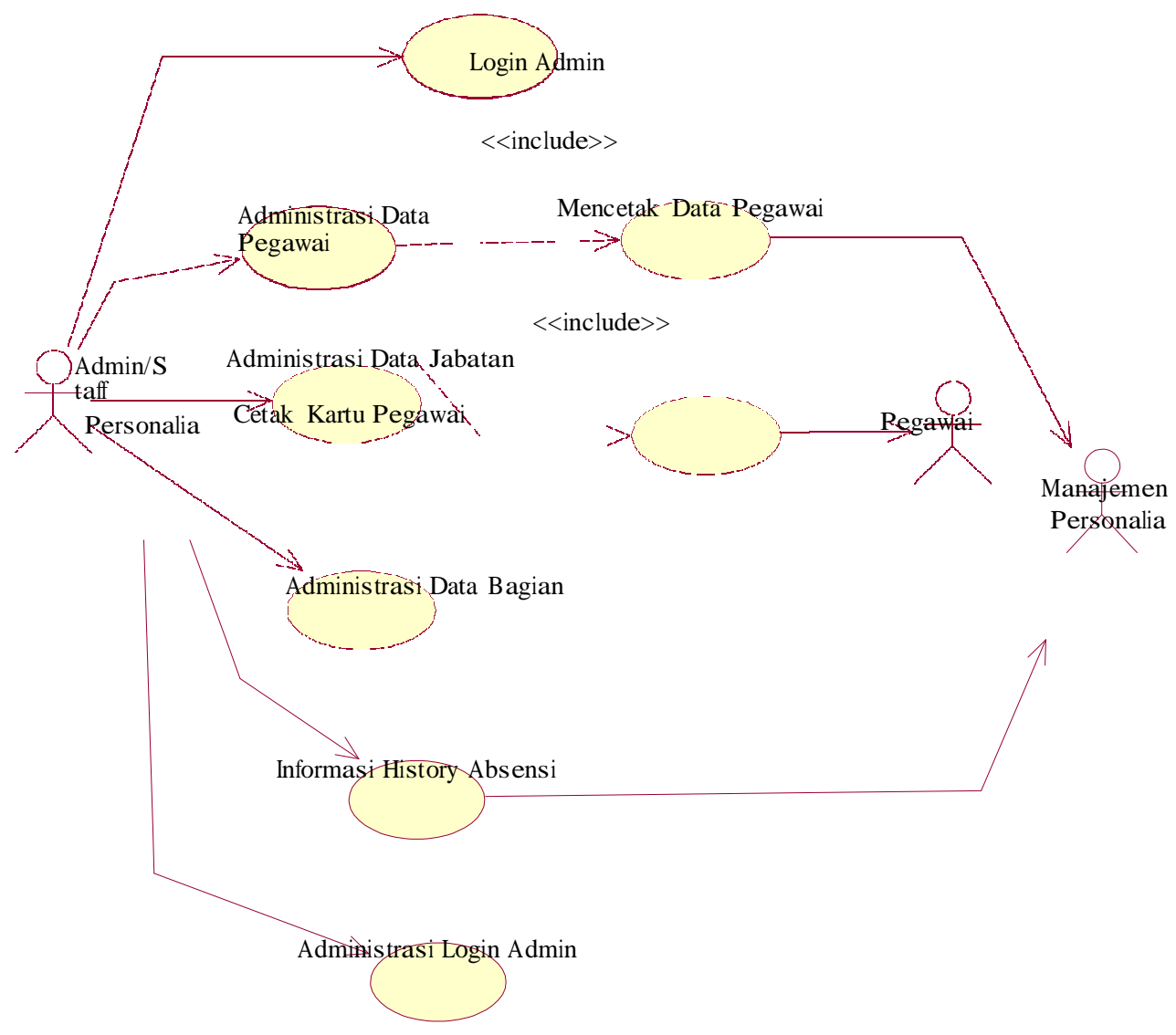




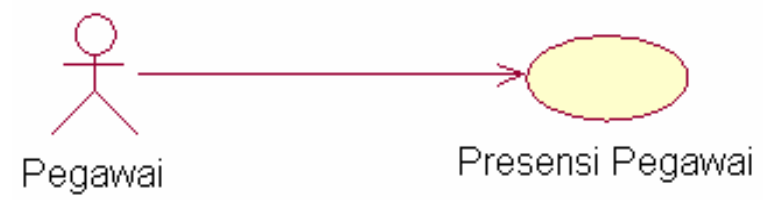

Gambar 3.3 Use Case Diagram Absensi Pegawai

\subsubsection{Sequence Diagram}

Sequence diagram ini menjelaskan secara detail urutan proses yang dilakukan dalam sistem untuk mencapai tujuan dari use case. Dalam Pengembangan sistem ini, ada beberapa sequence diagram antara lain :

1. Sequence Diagram Login Admin

Pada sequence diagram ini dijelaskan bagaimana actor ingin berinteraksi dengan sistem agar actor tersebut dapat melakukan proses login ke dalam sistem aplikasi absensi ini.

2. Sequence Diagram Administrasi Login Admin

Pada sequence diagram ini $d$ ijelaskan bagaimana actor harus melakukan pendaftaran username dan password sebelum actor tersebut dapat melakukan proses login ke dalam sistem aplikasi absensi ini.

3. Sequence Diagram Cetak Kartu Pegawai

Pada sequence diagram ini dijelaskan bagaimana actor (Admin/Staff Personalia) mencetak kartu ID untuk setiap masing-masing pegawai yang telah terdaftar pada sistem aplikasi ini.

4. Sequence Diagram Data Bagian

Pada sequence diagram ini dijelaskan bagaimana actor mendaftarkan data bagian ke dalam aplikasi absensi ini.

5. Sequence Diagram Data Jaba$\tan$

Pada sequence diagram ini dijelaskan bagaimana actor mendaftarkan data jabatan ke dalam aplikasi absensi ini.

6. Sequence Diagram Data

Pegawai

Pada sequence diagram ini dijelaskan bagaimana actor mendaftarkan data Pegawai ke dalam aplikasi absensi ini.

7. Sequence Diagram Informasi History Absensi

Pada sequence diagram ini dijelaskan bagaimana actor mencari data absensi pegawai dan menampilkannya serta melaporkannya untuk proses validasi ke bagian manajemen personalia.

7. Sequence Diagram Mencetak

Data Pegawai

Pada sequence diagram ini dijelaskan bagaimana actor 
mencari data pegawai dan menampilkannya serta melaporkannya untuk proses validasi ke bagian manajemen personalia.

9. Sequence Diagram Presensi Pegawai

Pada sequence diagram ini dijelaskan bagaimana actor (pegawai) melakukan proses absensi dalam waktu sehari, baik ketka waktu datang, waktu pulang, dan penghitungan total waktu kerja untuk dapat dimasukkan dalam laporan presensi pegawai.

\subsubsection{Class Diagram}

Class diagram ini digunakan untuk menggambarkan disain statis dari sistem yang akan dibangun yang memperlihatkan himpunan kelas, antarmuka, kolaborasi, dan relasi yang terdapat dalam aplikasi absensi ini.

3.8.4 Analisis Masukan dan Keluaran

Beberapa data yang akan menjadi masukan/input dalam sistem ini adalah :

1. Data Pegawai, Merupakan data pribadi pegawai yang meliputi beberapa keterangan tambahan seperti bagian, jabatan, dan keterangan lainnya.

2. Data Hadir Pegawai, Meliputi data tentang waktu kedatangan, dan waktu kepulangan pegawai
Sedangkan data keluaran dari sistem ini adalah :

1. Data presensi pegawai

2. Laporan akhir data presensi pegawai

3. Laporan akhir total waktu dan persentase waktu presensi pegawai

4. History data presensi

\subsubsection{Perancangan Basis Data}

Setelah dilakukan perancangan sistem, selanjutnya dilakukan perancangan database yang bertujuan untuk menggambarkan hubungan antar entity. Database merupakan kumpulan file-file yang saling berkaitan. Pada model data relational hubungan antara file direlasikan dengan kunci relasi (relation key), yang merupakan kunci utama dari masing-masing file. Perancangan database yang dibuat penulis terdiri dari normalisasi, ERD dan struktur data.

Perancangan basis data ini termasuk didalamnya meliputi bentukan E/R Diagram yang berikutnya akan diimplementasikan dalam bentuk tabel-tabel dengan keterkaitan atau keterhubungannya diantara tabel tersebut.

Fungsional dependensi diagram awal aplikasi absensi ini dapat terlihat pada gambar di bawah ini : 


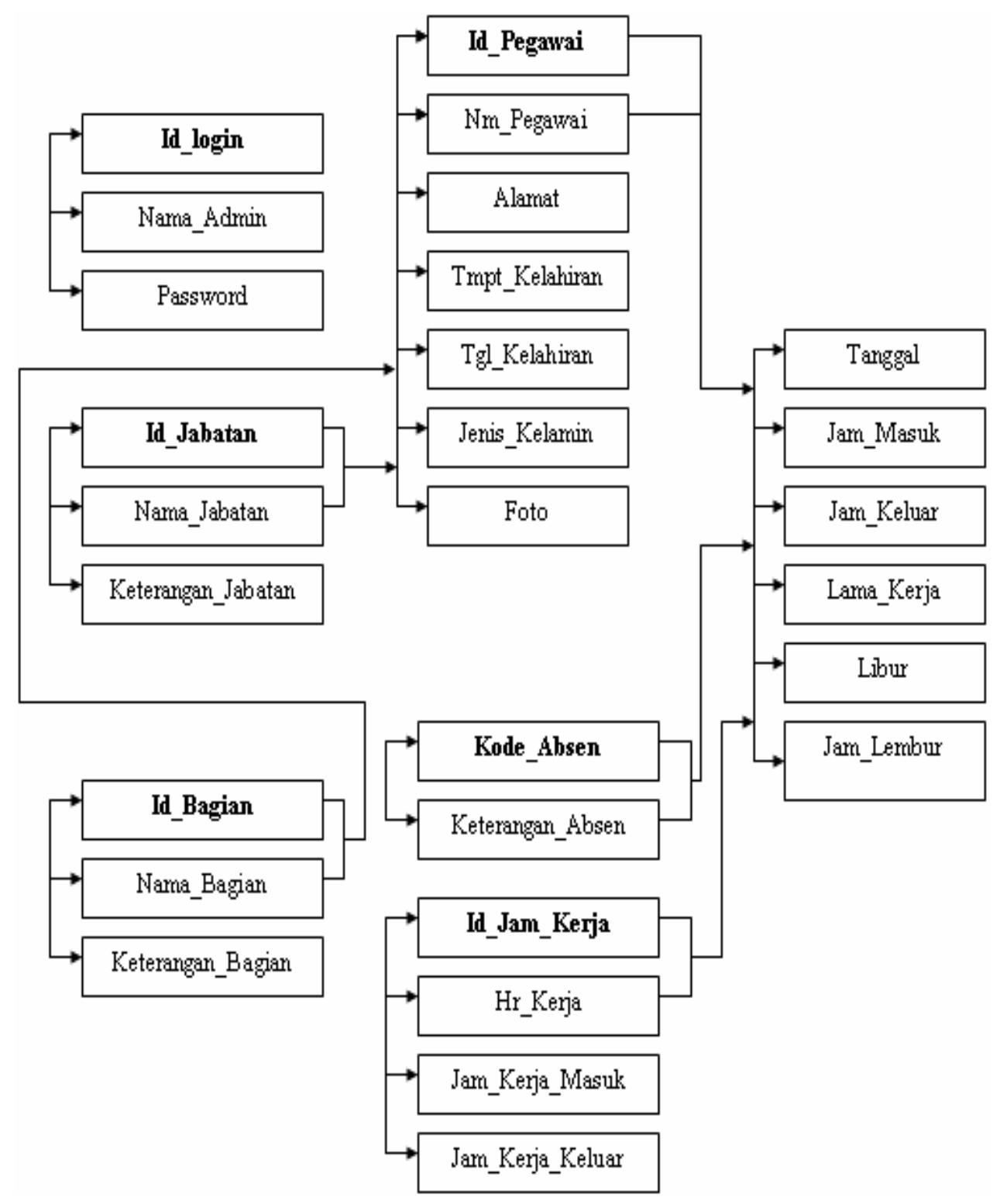

Gambar 4.4 Fungsional Dependensi Diagram Awal Database Aplikasi Absensi 


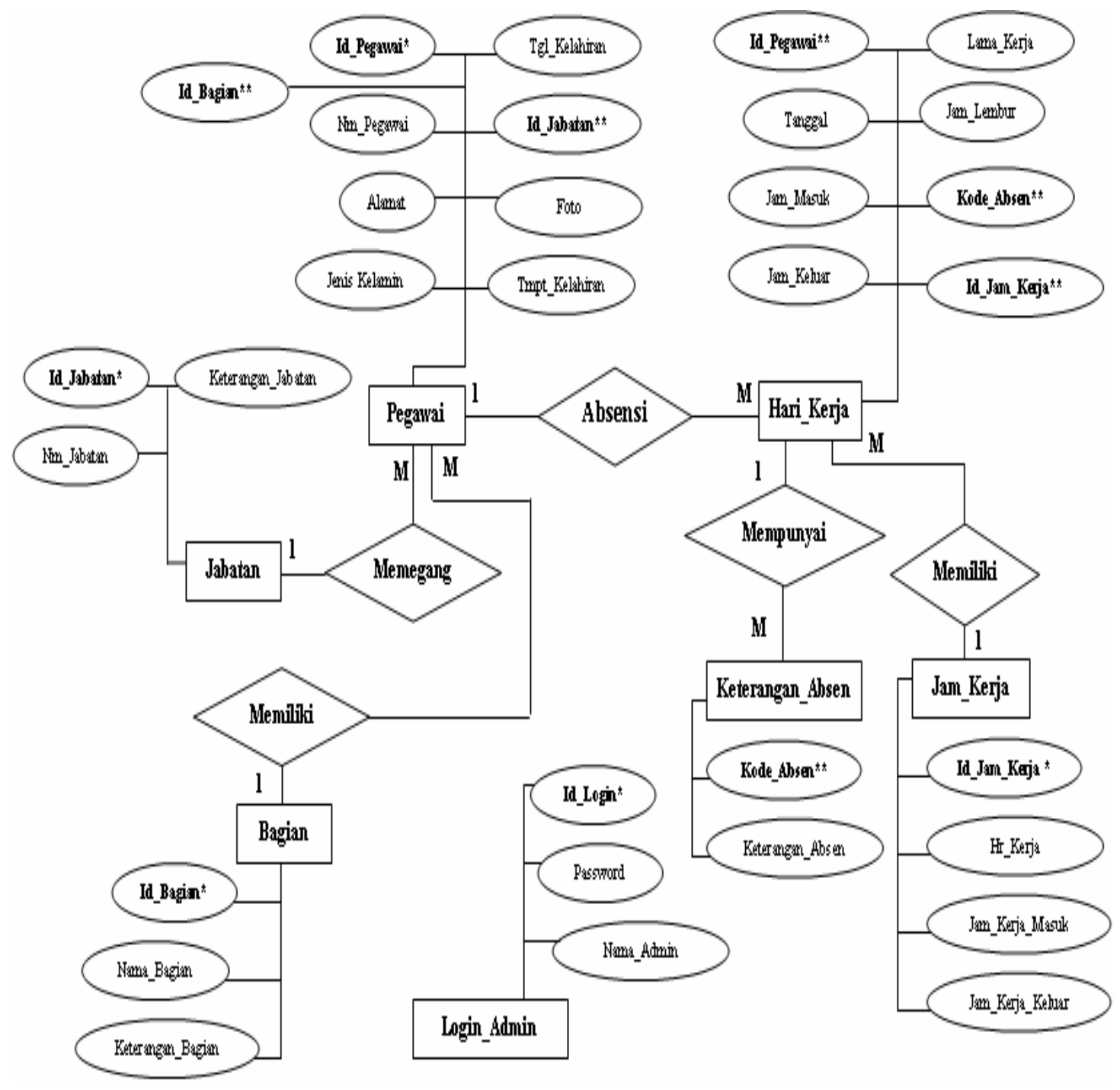

Gambar 4.7 Bentuk Normalize ER Diagram

3.8.5 Perancangan Antar Muka

1. Form Login

Form ini merupakan form yang mengharuskan user atau administrator untuk mengisi username dan password sebagai hak akses untuk dapat memodifikasi hal-hal yang berkaitan dengan data dan informasi di dalam aplikasi absensi pegawai ini. 


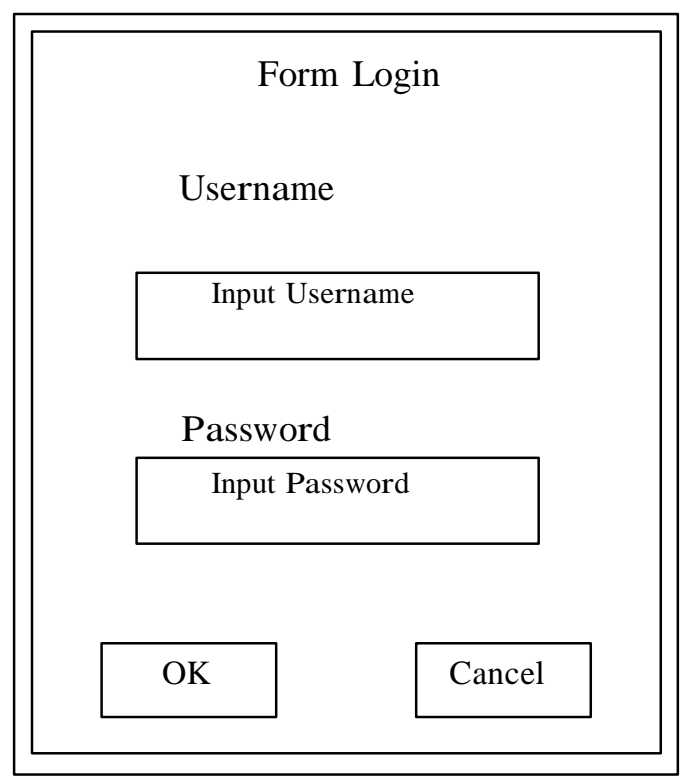

3. Form Absensi

Form ini merupakan form yang akan digunakan pegawai untuk menginputkan ID Pegawai sebagai penanda absensi, dimana pegawai harus menginputkan ID-nya sebanyak 2 kali untuk menandakan jam kehadiran dan jam kepulangan yang akan disimpan sebagai daftar kehadiran pegawai dengan penghitungan total waktu kerja didalamnya. Pegawai akan menginputkan ID pegawai yang berbentuk barcode yang tertera di dalam kartu pegawai pada barcode scanner yang telah disediakan.

Form absensi ini dapat dilihat pada gambar 4.13 di bawah ini: 


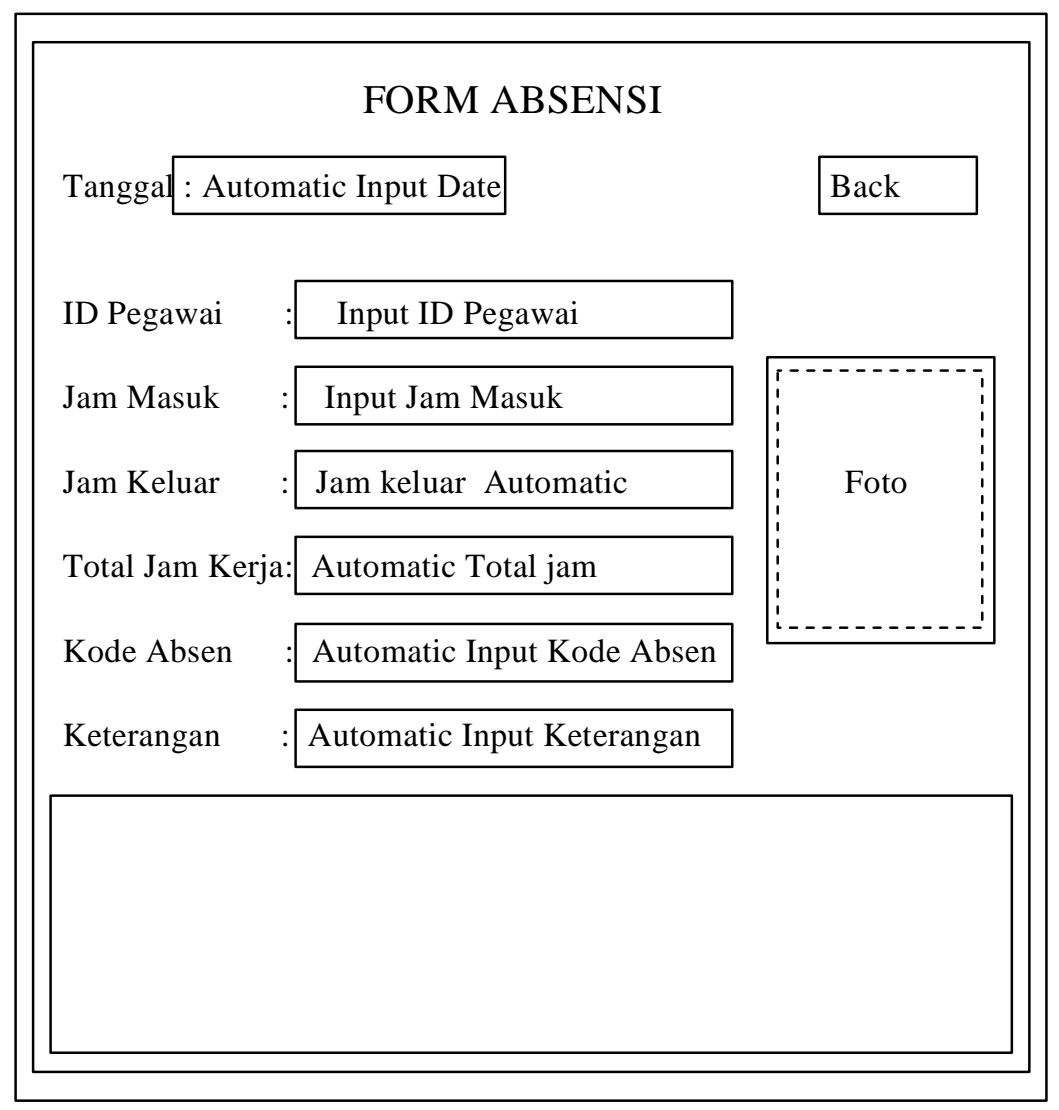

4. Form Data Pegawai

Form Data pegawai digunakan untuk melakukan penginputan data pribadi karyawan, dimana data karyawan ini akan diperlukan jika seorang pegawai hendak me- lakukan proses absensi. Form ini diisi oleh admin sesuai dengan data karyawan asli.

Form data pegawai dapat dilihat pada gambar di bawah ini : 


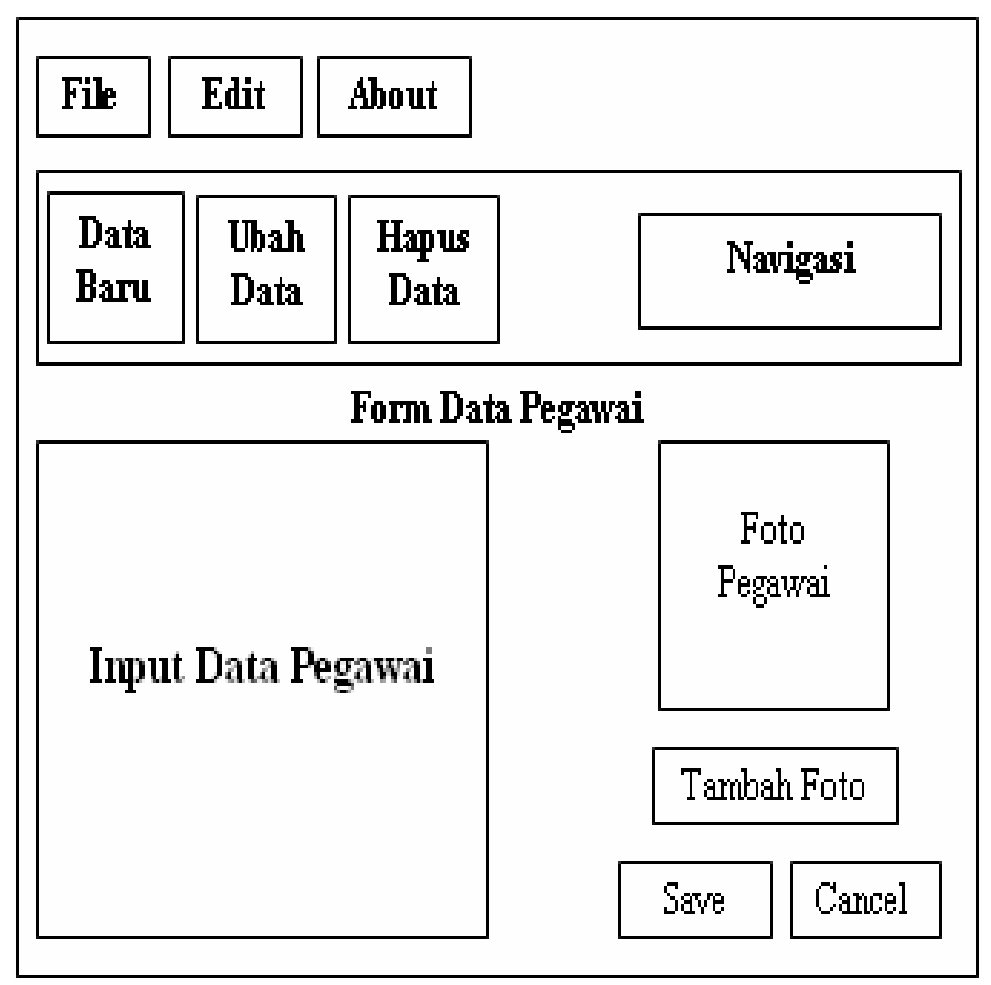

5. Form Utama

Form ini merupakan form menu utama yang terdiri dari berbagai tombol yang telah terintegrasi untuk menampilkan menu lain dalam aplikasi absensi pegawai ini. Tombol-tombol yang ada dalam menu utama ini antara lain: Menu Pegawai, Menu Absensi, Laporan Pegawai, dan Laporan Absensi. Rancangan menu utama ini dapat dilihat pada gambar dibawah ini : 


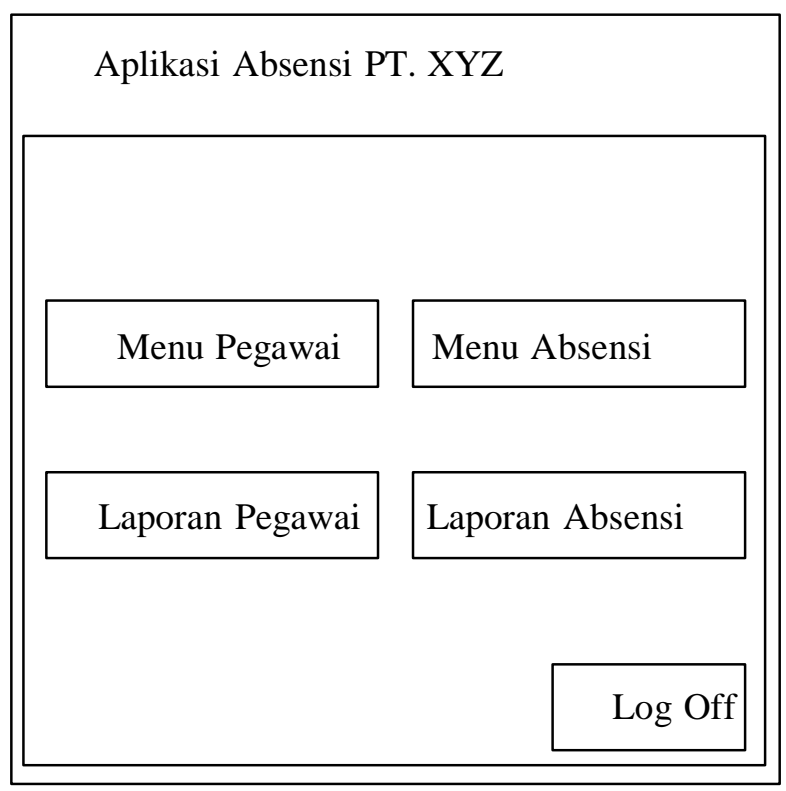

6. Form Laporan Pegawai

Form laporan pegawai ini digunakan untuk memberikan suatu data pelaporan dan detail laporan pegawai yang bekerja pada perusahaan yang ber- sangkutan yang terdiri dari keterangan pribadi pegawai. Rancangan form laporan pegawai ini dapat dilihat padagambar 4.25 di bawah ini :

Form Laporan Pegawai

Input Pencarian Data

Pegawai Berdasarkan

Nama dan ID Pegawai

List Data Laporan Pegawai

Lihat
Laporan


7. Form Laporan Absensi

Form laporan absensi ini digunakan untuk memberikan suatu data pelaporan dan detail laporan absensi pegawai mulai dari jam masuk, jam keluar, total waktu kerja dan keterangan yang lainnya. Rancangan form laporan absensi ini dapat dilihat pada gambar 4.27 di bawah ini :

\section{Form Laporan Absensi}

Input Pencarian Data Absensi

Berdasarkan ID Pegawai dan Tanggal Absensi

List Data Laporan Absensi

\section{Form Cetak Kartu ID}

Form ini digunakan untuk mencetak kartu ID pegawai yang terdiri dari Input Nama Pegawai, ID Pegawai, Bagian dan Jabatan. Pada form ini, dari nomor ID pegawai yang bersangkutan akan di- bentuk suatu kode barcode, yang nantinya akan digunakan dalam proses absensi. Rancangan Form Cetak Kartu ID ini dapat dilihat pada gambar di bawah ini: 
Form Cetak Kartu ID

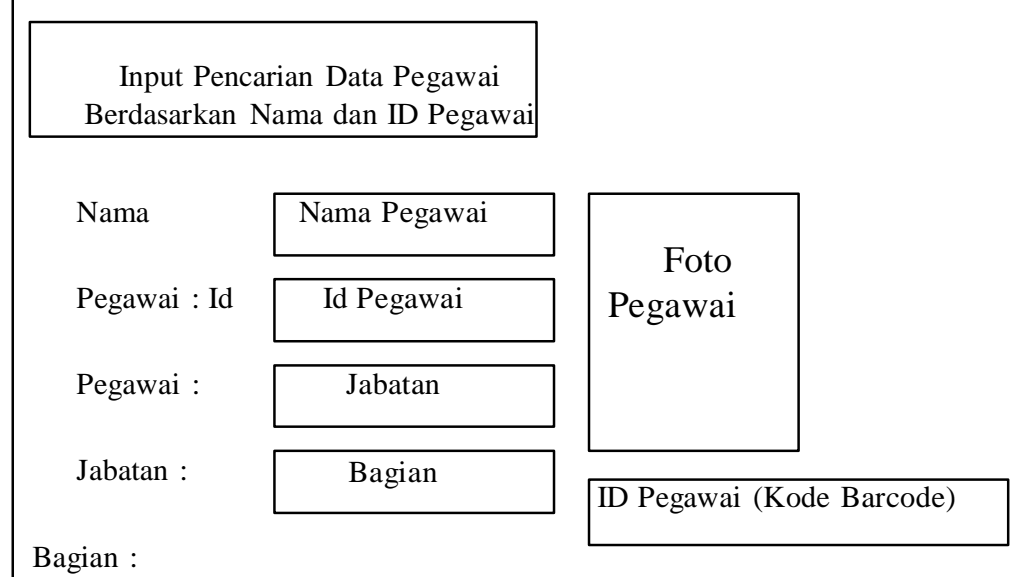

Bagian :

List Data Pegawai

9. Form Login Admin

Form ini digunakan untuk mendata dan mendaftarkan nama dan password administrator yang memiliki hak akses untuk me- ngelola dan bertanggung jawab terhadap aplikasi absensi ini. Rancangan Form Login admin ini dapat dilihat pada gambar di bawah ini: 


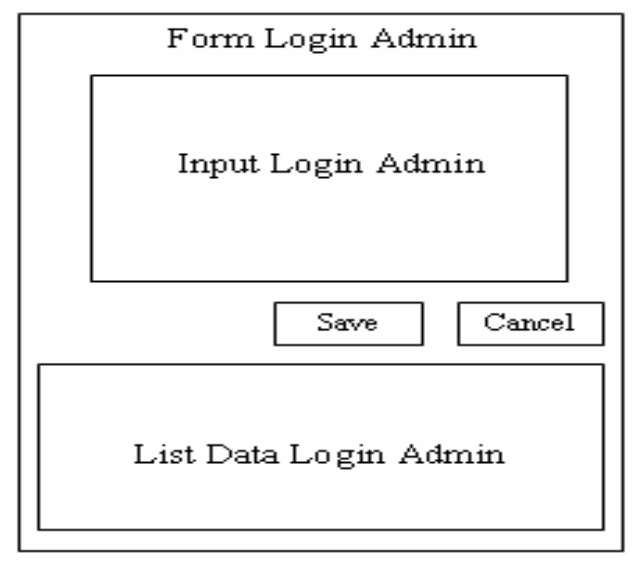

10. Rancangan Report Pegawai

XYZ beserta detail Report pegawai ini digunakan untuk melaporkan daftar dan data seluruh karyawan yang bekerja pada PT. bagian dan jabatan dimana pegawai tersebut bekerja. Rancangan report pegawai dapat dilihat pada gambar di bawah ini :

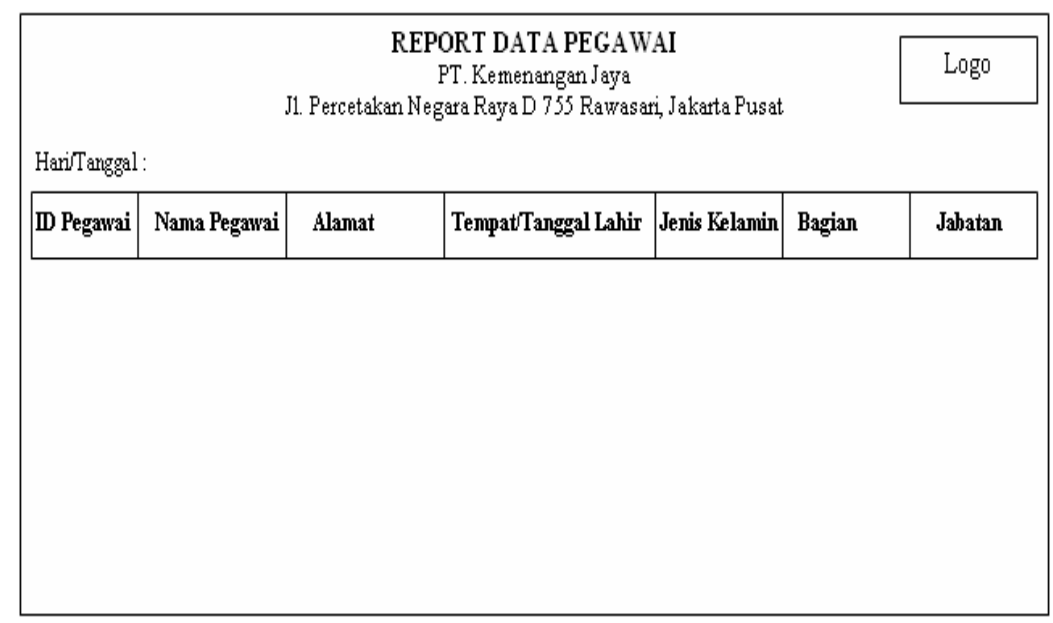

11. Rancangan Report Absensi Pegawai

Report absensi pegawai ini digunakan untuk melaporkan daftar dan data absensi seluruh karyawan yang bekerja pada PT. XYZ beserta detail keterangan presensi pegawai tersebut. Rancangan report absensi pegawai dapat dilihat pada gambar $4.34 \mathrm{di}$ bawah ini : 


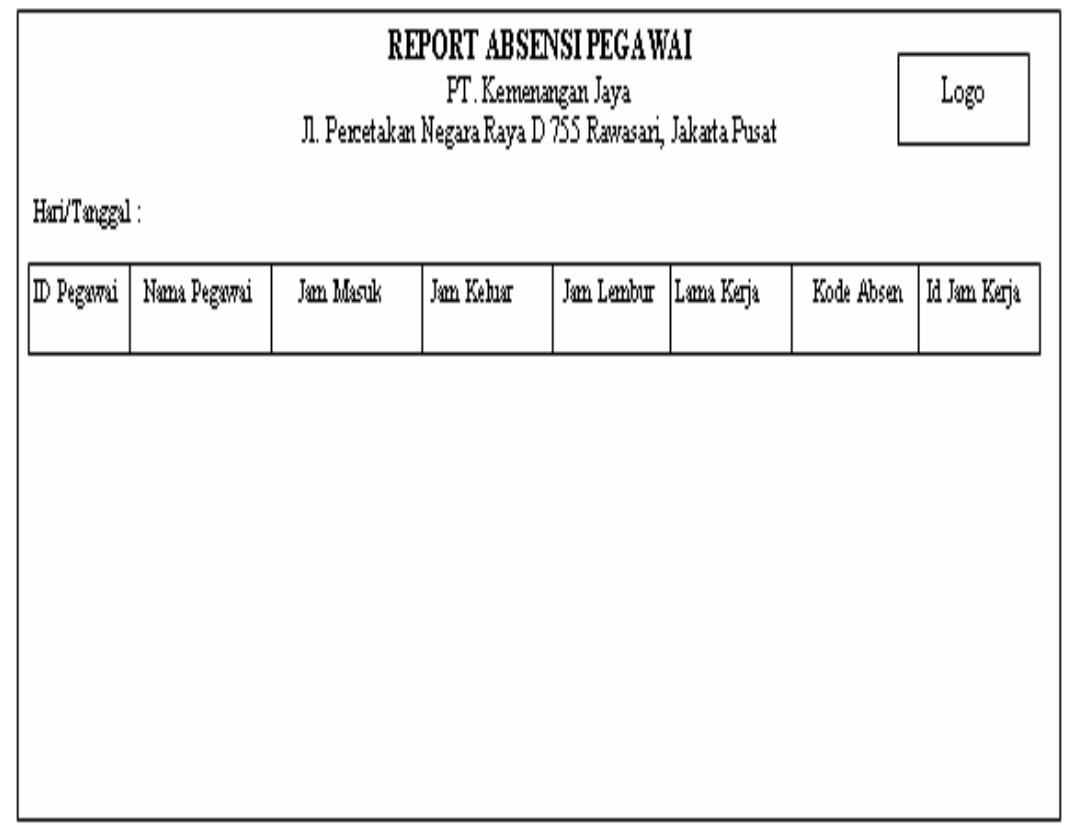

\section{PENUTUP}

4.1. Kesimpulan

1. Perubahan sistem absensi manual menjadi suatu sistem yang terkomputerisasi dengan penambahan sistem barcode dilakukan agar tingkat kesalahan dalam melakukan absensi dapat diminimalisir dan dapat memberikan pelayanan lebih baik serta hasil keluaran atau laporan yang dibutuhkan sesuai dengan yang diharapkan.

2. Sistem aplikasi absensi yang baru ini akan lebih memudahkan proses kontrol absensi kehadiran karyawan dan mampu memberikan laporan akhir absensi yang dibutuhkan.

3. Dengan system pendataan absensi karyawan terkomputerisasi ini, bagian pendataan karyawan dapat dengan cepat dalam melakukan penginputan data dan memberikan kemudahan dalam pencarian data karyawan.

4. Aplikasi absensi karyawan dengan metode barcode ini akan memberikan kemudahan dalam melakukan pendataan kehadiran karena adanya interface aplikasi dan penggunaannya yang user friendly.

\subsection{Saran}

1. Bagi yang berminat untuk pengembangan selanjutnya, sebaiknya dilakukan dengan menggunakan metode lain seperti Smart Handkey-CR atau dengan Fingerprint Scan System.

2. Untuk pengembangan selanjutnya diharapkan bias diterapkan 
pada semua Operating System seperti Linux dan FreeBSD.

3. Harus dilakukan pelatihan bagi admin, terutama yang menggunakan aplikasi ini dan adanya petugas khusus yang akan memelihara aplikasi ini, sehingga kinerja aplikasi ini dapat berjalan dengan baik.

4. Database sistem ini minimal satu atau dua minggu sekali di backup oleh pihak yang bertanggung jawab terhadap sistem tersebut, dalam hal ini perlu adanya suatu back office yang bertanggung jawab akan entri data, pemeriksaan data untuk menghindari hilangnya database jika terjadi suatu kesalahan, maupun kejadian lain yang tidak diharapkan dan di luar kemampuan kita untuk menghindarinya seperti bencana alam.

5. Untuk implementasi awal (1 sampai 2 bulan pertama), setiap hari database harus dikontrol untuk menghindari ketidak teraturan database yang ada untuk menghindari terjadinya human error dalam penggunaan sistem.

\section{DAFTAR PUSTAKA}

HM. Jogiyanto, Analisis dan Desain Sistem Informasi, Yogyakarta, Andi Offset, 2005

Fathansyah, Basis Data, Bandung, Informatika, 1999

Teguh Wahyono, Sistem Informasi (konsep dasar, analisis desain dan implementasi), Yogyakarta, Graha Ilmu, 2004

Tata Sutabri, Analisa Sistem Informasi, Yogyakarta, Andi Offset, 2004

\section{Edhy Sutanta, Sistem Informasi Manajemen, Yogyakarta, Graha Ilmu, 2003}

